\title{
INHIBITION KINETICS OF Sida rhombifolia L. EXTRACT TOWARD XANTHINE OXIDASE BY ELECTROCHEMICAL METHOD
}

\author{
Dyah Iswantini ${ }^{1,2, *}$, Muammar Yulian ${ }^{1,3}$, Sri Mulijani ${ }^{1}$, and Trivadila ${ }^{1,2}$ \\ ${ }^{1}$ Department of Chemistry, Faculty of Mathematics and Natural Sciences, Bogor Agricultural University, \\ Jl. Agatis Kampus IPB Darmaga, Bogor, West Java, 16680, Indonesia \\ ${ }^{2}$ Biopharmaca Research Center, Bogor Agricultural University, \\ Jl. Taman Kencana No 3, Bogor, West Java, 16151, Indonesia \\ ${ }^{3}$ Ar-Raniry State Islamic University, Banda Aceh, 23111, Indonesia \\ Received August 25, 2013; Accepted January 8, 2014
}

\begin{abstract}
Sida rhombifolia $L$. is a traditional medicinal plant that has been known with potential as antigout. The previous research suggested that flavonoids crude extract of $S$. rhombifolia had an inhibitory activity toward xanthine oxidase by $71 \%$ and a spectrophotometric measurement showed that the type of flavonoids crude extract inhibition was a competitive inhibition. The purpose of the research was to investigate the type of inhibition kinetic of $\underline{S}$. Rhombifolia's ethanol extract by electrochemical method and to compare the measurements of linearity and sensitivity between spectrophotometric and electrochemical methods. The results showed that the yield of $\underline{S}$. Rhombifolia's ethanol extract was $9.82 \%$ with the inhibitory activity ranging from $13.64 \%$ to $82.69 \%\left(5.00-200 \mathrm{mg} \mathrm{L}^{-1}\right)$ and $I_{50}$ value was $91.15 \pm 5.74 \mathrm{mg} \mathrm{L}^{-1}$. Allopurinol as a control showed the inhibitory activity of $15.26-70.95 \%\left(0.10-4.00 \mathrm{mg} \mathrm{L}^{-1}\right)$ and $I C_{50}$ value was $2.45 \pm 2.21 \mathrm{mg} \mathrm{L}^{-1}$. Inhibition kinetics of the ethanol extract caused a $K_{M}$ increase and unchange of $V_{M A x}$. Based on the data, the type of inhibition kinetics was a competitive inhibition, with an inhibitor affinity (a) value of 3.18. Linearity of xanthine oxidase activity assay by electrochemical and spectrophotometric methods showed the range of 0.01-1.00 $\mathrm{mM}\left(R^{2}=0.978\right)$ and 0.05-0.70 $\mathrm{mM}\left(R^{2}=0.977\right)$ respectively. The sensitivity of electrochemical method was reported higher $\left(0.95 \mu \mathrm{A} \mathrm{mM}{ }^{-1}\right)$ than the spectrophotometric method $\left(0.007 \mathrm{~min}^{-1}\right)$.
\end{abstract}

Keywords: inhibition kinetics; Sida rhombifolia L.; xanthine oxidase; electrochemical method

\section{ABSTRAK}

Sida rhombifolia L. merupakan tanaman obat yang telah diketahui memiliki potensi sebagai antigout. Penelitian terdahulu menunjukkan bahwa ekstrak flavonoid sidaguri memiliki daya inhibisi terhadap enzim xantina oksidase hingga $71 \%$ dan pengukuran secara spektrofotometri menunjukkan ekstrak flavonoid tumbuhan ini mengikuti mekanisme inhibisi kompetitif. Tujuan penelitian ini adalah untuk menentukan tipe kinetika inhibisi dari ekstrak etanol herba sidaguri dengan metode elektrokimia serta membandingkan linearitas dan sensitivitas pengukuran antara metode spektrofotometri dan elektrokimia. Hasil penelitian menghasilkan rendemen ekstrak etanol sebesar 9,82\%

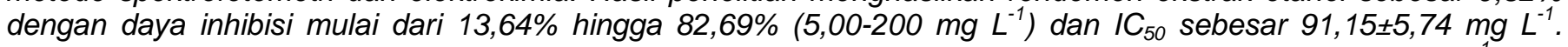
Adapun allopurinol sebagai kontrol diketahui memiliki daya inhibisi sebesar 15,26-70,95\% (0,10-4,00 $\left.\mathrm{mg} \mathrm{L}^{-1}\right)$ dan

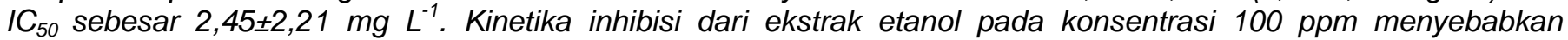
peningkatan nilai $K_{M}(0,187 \mathrm{mM}$ atau meningkat sebesar 68,73\%) dari 0,0855 mM menjadi 0,2718 $\mathrm{mM}$, tanpa mengalami perubahan $V_{\text {maks. }}$. Berdasarkan hasil tersebut dapat dikatakan tipe kinetika inhibisi yang terjadi mengarah pada tipe kinetika inhibisi kompetitif dengan nilai afinitas inhibitor $(\alpha)$ sebesar 3,18. Metode elektrokimia menunjukkan linearitas pengukuran yang lebih baik dibandingkan metode spektrofotometri, masing-masing pada rentang 0,01-1,00 mM $\left(R^{2}=0,978\right)$ dan 0,05-0,70 $\mathrm{mM}\left(R^{2}=0,977\right)$. Sensitivitas metode elektrokimia $\left(0,95 \mu \mathrm{Am} \mathrm{m}^{-1}\right)$ juga lebih baik dibandingkan metode spektrofotometri $\left(0,007 \mathrm{~min}^{-1}\right)$.

Kata Kunci: kinetika inhibisi; Sida rhombifolia L.; xantina oksidase; elektrokimia

\section{INTRODUCTION}

Uric acid is final product of purine metabolism. Abnormal conditions of uric acid metabolism will cause precipitation of sodium urate crystals in joints, a condition termed gout. Gout is caused by an imbalance between the production and excretion of uric acid [1]. Xanthine oxidase $(\mathrm{XO})$ is an enzyme that plays an

\footnotetext{
* Corresponding author. Tel/Fax : +62-251-8624567/8624567

Email address : dyahprado@yahoo.co.id
} 
important role in purine metabolism and functions to catalyze hypoxanthine oxidation into xanthine and, xanthine into uric acid. The well known xanthine oxidase inhibitors (XOIs) is allopurinol, which is one option out of the many synthetic drugs used in modern medicine for the treatment of gout [2]. Nevertheless, the use of allopurinol can cause side effects such as allergies, fever, and gastrointestinal disorders. The side effects of synthetic drug use such as allopurinol have prompted people to turn to traditional medicine that utilizes herbs (medicinal herbs) which is safer and more effective.

Sida rhombifolia $L$. is one of a traditional medicinal plant that has been known with potential as antigout. Iswantini et al. [3] reported that flavonoids crude extract of this plant has a high inhibitory activity of $\mathrm{XO}$, ranging from 48 to $71 \%\left(100-800 \mathrm{mg} \mathrm{L}^{-1}\right)$. Not only in a single composition, Sida rhombifolia L. potential as antigout in the combined formula has a higher inhibitory activity compared to allopurinol, and this result has been patented and has been granted [4]. In addition to its potential as antigout, the inhibition kinetics determination of $S$. Rhombifolia's extract as a drug candidate is also one very important thing. The determination of inhibition kinetics type which is formed can subsequently explain the inhibitory mechanism formed and describe the affinity formed between $\mathrm{XO}$ enzyme as a target with drug candidate compounds, whether it is temporary (competitive inhibition and uncompetitive inhibition) or permanent (non-competitive inhibition).

Flavonoids crude extract of $S$. Rhombifolia was found out to show the competitive inhibition toward $X O$ [3]. Luteolin and quercetin were reported to follow the competitive inhibition against $X O$ [5]. A noncompetitive inhibition of $\mathrm{XO}$, among others, is indicated by Fraxinus angustifolia leaf extract [6] and Tephrosia purpurea root extract [7], while the caulerpenyne (CYN) from the extract of Caulerpa prolifera was reported to show the uncompetitive inhibition [8].

Method that is commonly and widely used to determine the type of inhibition kinetics is spectrophotometry. Spectrophotometric method is now becoming obsolete, because it is less specific, expensive, highly sensitive to light and is affected by turbidity [9-10]. Therefore, there should be a method which is easier, accurate, rapid and sensitive in the determination of the type of inhibition kinetics. Campanella et al. [11] reported that the electrochemical method was more effective and selective and could overcome the weaknesses of the spectrophotometric method. This method is very promising because of the relatively fast analysis time, which requires inexpensive instrument, accurate, easy miniaturization, and simple operation protocols [12-13]. Electrochemical method for determination of uric acid which have been developed by Arslan [14] using the immobilized uricase with glutaraldehyde on polyaniline-polypyrrole (pani-ppy) composite film by crosslinking procedure on the surface of a platinum electrode. Ivekovic et al. [15] developed amperometric uric acid biosensor based on uricase with $\mathrm{H}_{2} \mathrm{O}_{2}$ transducer and electrode modified with Prussian blue.

The purpose of research was to investigate the type of inhibition kinetics of S. Rhombifolia's ethanol extract using an electrochemical method and to compare the measurements of the linearity and sensitivity between electrochemical and spectrophotometric methods.

\section{EXPERIMENTAL SECTION}

\section{Materials}

Sida rhombifolia L. Plants were collected from its natural habitat in Bogor, East Java, Indonesia.

\section{Instrumentation}

Instuments used in this research were an eDAQ potensiostat (Ecorder 410), and data processing software of Echem $v$ 2.1.0. In which an $\mathrm{Ag} / \mathrm{AgCl}$ electrode, a platinum disk, and carbon paste electrode were used as the reference, counter electrode, and working electrode, respectively, and spectrophotometer.

\section{Procedure}

\section{Preparations of carbon paste electrode}

Preparations of carbon paste electrode referred to Mirrel et al. [16] with modification. A carbon paste was made from a mixture of graphite powder and paraffin liquid with ratio 2:1 into one end of a glass tubing, and the surface was smoothed and cleaned with a piece of waxed paper. Finally, electrode surface was coated with a dialysis membrane, covered with nylon fibre and tied with parafilm.

\section{Electrochemical measurements}

Electrochemical measurements were carried out using an eDAQ potensiostat (Ecorder 410), and data processing software of Echem $v$ 2.1.0. In which an $\mathrm{Ag} / \mathrm{AgCl}$ electrode, a platinum disk, and carbon paste electrode were used as the reference, counter electrode, and working electrode, respectively. The measurements were performed with an electrolysis cell containing $1.9 \mathrm{~mL}$ of basal solution of phosphate buffer $50 \mathrm{mM}$ with predetermined optimum $\mathrm{pH}$. The test solution was deaerated by passing over nitrogen gas unless stated otherwise. The change of currents 
response after each addition were observed and recorded.

\section{The inhibitory assay against $X O$}

The inhibitory assay were measured at optimum conditions have been determined previously. The potent inhibitory activity (\%) of the crude extract was determined by changes in the XO activity which is analogous to current (I) before and after the addition of extract. Extract concentration varied in the range of 5-200 $\mathrm{mg} \mathrm{L}^{-1}$. In addition, the inhibitory activity of allopurinol as a control was also determined by the same procedure.

\section{The Kinetic inhibition assay against $X O$}

The assay was only done on the extract concentration closest to the $I_{50}$ value. The type of extract inhibition kinetics was determined by analysis of the Lineweaver-Burk plot. This kinetics study was carried out in the absence and presence of extract with varying concentration of xanthine as the substrate.

\section{Spectrophotometric measurements}

Spectrophotometric measurement referred to Tamta et al. [17] which was modified for the determination of velocity assumed as XO activity. Into a tube was inserted $1.9 \mathrm{~mL}$ phosphate buffer $50 \mathrm{mM} \mathrm{pH}$ 7.5. One milliliter xanthine and $0.1 \mathrm{~mL}$ xanthine oxidase $0.1 \mathrm{U} / \mathrm{mL}$ were added, and then the solution was incubated at room temperature for $45 \mathrm{~min}$. After the incubation, $1 \mathrm{~mL} \mathrm{HCl} 0.58 \mathrm{M}$ was immediately added to terminate the reaction. The absorbances of the mixed solution were measured at $269.5 \mathrm{~nm}$.

\section{RESULT AND DISCUSSION}

\section{Extraction}

The dried sample yielded $9.81 \%$ of crude extract. Ethanol was used as extracting material because it has two groups with different polarity, i.e. the hydroxyl group which is polar and the alkyl group which is non-polar. Polar and nonpolar compound in the sample are expected to be extracted into the ethanol in the presence of the two groups.

\section{Inhibitory Assay of the Extract against XO}

Performance of enzyme activity is generally affected by temperature, $\mathrm{pH}$, and substrate concentration. Therefore, optimization of $\mathrm{XO}$ activity was done to study the effects of these parameters on XO activity. Optimized parameters include temperature (25-35 $\left.{ }^{\circ} \mathrm{C}\right), \mathrm{pH}$ [6-9], and substrate concentrations $(0.10-1.00 \mathrm{mM})$. Based on those contours (data not
Table 1. Potent inhibitory effect (\%) of several concentration of extract on the activity of xanthine oxidase

\begin{tabular}{cccc}
\hline No & $\begin{array}{c}\text { [S. Rhombifolia] } \\
(\mathrm{ppm})\end{array}$ & $\begin{array}{c}\text { Current } \Delta \mathrm{I}_{\mathrm{pa}} \\
(\mu \mathrm{A})\end{array}$ & $\begin{array}{c}\text { Inhibitory Effect } \\
(\%)\end{array}$ \\
\hline 1 & 0 & 1.173 & 0 \\
2 & 5 & 1.013 & 13.640 \\
3 & 10 & 0.833 & 28.986 \\
4 & 20 & 0.810 & 30.946 \\
5 & 50 & 0.747 & 36.317 \\
6 & 100 & 0.513 & 56.266 \\
7 & 200 & 0.203 & 82.694 \\
\hline
\end{tabular}

Table 2. Potent inhibitory effect of several concentration of allopurinol on the activity of xanthine oxidase

\begin{tabular}{cccc}
\hline No & $\begin{array}{c}\text { [allopurinol] } \\
(\mathrm{ppm})\end{array}$ & $\begin{array}{c}\text { Current } \Delta \mathrm{I}_{\mathrm{pa}} \\
(\mu \mathrm{A})\end{array}$ & $\begin{array}{c}\text { Inhibitory Effect } \\
(\%)\end{array}$ \\
\hline 1 & 0 & 1.160 & 0 \\
2 & 0.1 & 0.983 & 15.259 \\
3 & 0.5 & 0.867 & 25.259 \\
4 & 1 & 0.783 & 32.500 \\
5 & 2 & 0.673 & 41.983 \\
6 & 3 & 0.487 & 58.017 \\
7 & 4 & 0.337 & 70.948 \\
\hline
\end{tabular}

shown), the optimum conditions for each of the parameter temperature, $\mathrm{pH}$ and xanthine concentration was $30^{\circ} \mathrm{C}, \mathrm{pH} 7.5$, and $1.00 \mathrm{mM}$. Kong et al. [18] was reported the condition of similar $\mathrm{pH}$. As for the other different measurement conditions, it was reported by CeCngiz et al. [8], that is, at a temperature of $37^{\circ} \mathrm{C}$ and $\mathrm{pH}$ 9.0. The differences in the optimum conditions for the measurement of temperature and substrate concentration are caused by different methods, tools and measurement time.

The potential of ethanol crude extract as antigout was determined by observing the inhibitory activity of the extract at various concentrations against $\mathrm{XO}$ activity. Analyses of these various concentrations were aimed to investigate the effects of the increase in the concentration on the inhibitory activity. In addition, concentration variation will facilitate and provide flexibility to the selection of the extract concentration to be used as a candidate on kinetics inhibition assay.

The results of extract inhibition effect can be seen in Table 1, which shows that there is an increase in inhibition effect in line with the increase in extract concentration. Linear relationship between the inhibition effect and extract concentration is shown by the decrease of current $(I)$ which is analogous to XO activity after the addition of extract at various concentrations. The $S$. Rhombifolia's ethanol extract is known to have inhibitory activity (\%) by $13.64 \%$ to $82.69 \%\left(5-200 \mathrm{mg} \mathrm{L}^{-1}\right)$. Iswantini et al. [3] previously reported that the inhibitory assay of flavonoid crude extract from this plant using the spectrophotometric 


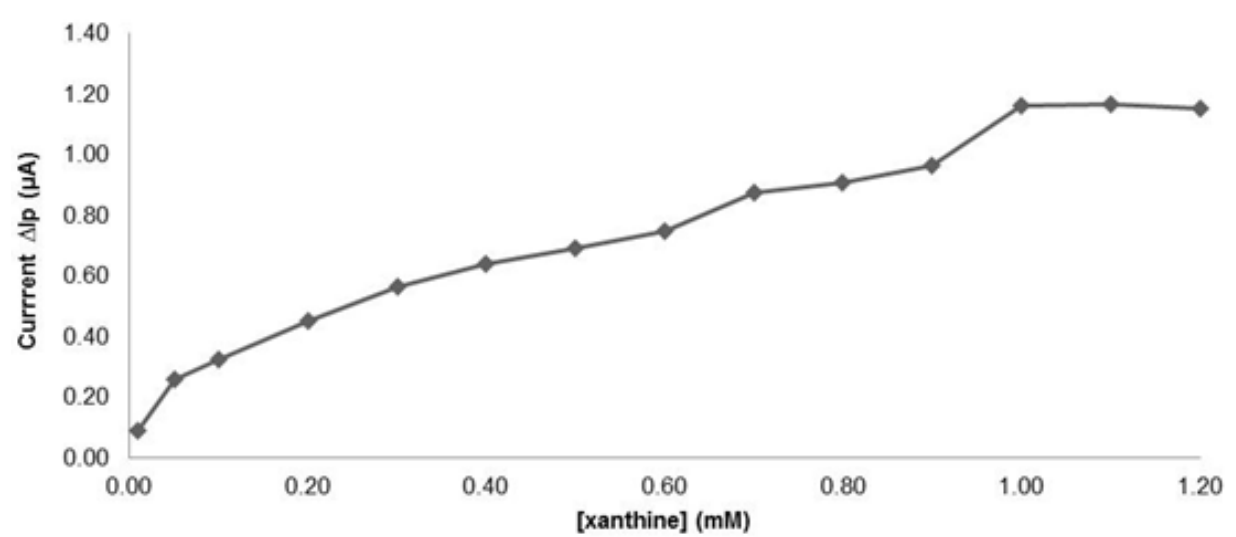

Fig 1. Relationships between xanthine concentration and current responses as $\mathrm{XO}$ activity

method showed an inhibitory activity of $48-70.71 \%$ at a concentration of $100-800 \mathrm{mg} \mathrm{L}^{-1}$.

The measurable differences of the inhibition effect in this study and Iswantini et al. [3] were presumably because the spectrophotometric measurement which is strongly influenced by the concentration of test solution so that the response becomes less good. It can be indicated that the electrochemical method can respond to the inhibitory activity of extracts better compared to the spectrophotometric method. According to Thuong et al. [19] a compound is said to be active if it has a value of $I_{50}$ less than $100 \mathrm{mg} \mathrm{L}^{-1}$. The results showed the $\mathrm{IC}_{50}$ values of extract of $91.15 \pm 5.74 \mathrm{mg} \mathrm{L}^{-1}$.

\section{Inhibitory Assay of Allopurinol against XO}

As comparison in this study, the inhibitory activity and $\mathrm{IC}_{50}$ of allopurinol (Table 2) were also determined. The analysis showed that allopurinol had a stronger inhibitory activity with $\mathrm{IC}_{50}$ value of $2.45 \pm 2.21 \mathrm{mg} \mathrm{L}^{-1}$. Other studies on allopurinol inhibitory activity indicated that $I_{50}$ allopurinol which is varied, among others, 6.1 $\mu \mathrm{g} \mathrm{mL}^{-1}$ [20-21], 3.74 $\mathrm{gg} \mathrm{mL}^{-1}$ [22] and $4.29 \mu \mathrm{g} \mathrm{mL}^{1}$ [23].

This indicated that the electrochemical method carried out in this study gave a value of $\mathrm{IC}_{50}$ which was relatively small compared with the spectrophotometric method reported by Umamaheswari et al. [20] and Azmi et al. [22]. However, several other studies have also reported the $\mathrm{IC}_{50}$ value which was relatively smaller at $0.6 \mu \mathrm{g} \mathrm{mL}{ }^{-1}$ [24]. $\mathrm{IC}_{50}$ values in some of these studies may be different because it is influenced by differences in observing conditions [25].

\section{Linearity and Sensitivity Measurement}

Effect of substrate concentration on the XO activity can be determined by measuring the activity of $\mathrm{XO}$ with varying concentrations of xanthine as the substrate. Fig. 1 which is identical to the Michaelis-Menten curve shows the relationship xanthine concentration and XO activity.
Reaction catalyzed by the enzyme was occured in two phases. First, if the substrate concentration is low, the enzyme active sites did not fully interact to the substrate. Second, when the substrate concentration increases, the active sites is bound entirely by substrate and at this time the enzyme has been working at full capacity so that the addition of substrate does not affect $X O$ activity [10]. When the concentration of xanthine is less than $1.00 \mathrm{mM}$, the reaction is in the first phase and when the xanthine concentration is greater than $1.00 \mathrm{mM}, \mathrm{XO}$ activity is in the second phase.

Fig. 2 shows the linear relationship between substrate concentration and current responses as $\mathrm{XO}$ activity by the electrochemical method in the range of 0.01-1.00 $\mathrm{mM}$. Linear range obtained in the electrochemical measurement is better when compared with the results obtained with the spectrophotometric method. The spectrophotometric measurement was carried out at the maximum wavelength $\left(\lambda_{\max }\right) 269.50$ $\mathrm{nm}$ and showed a linear measurement in the substrate concentration range of $0.05-0.70 \mathrm{mM}$ (Fig. 3). Spectrophotometric measurement gave high absorbance $(>2)$ at the substrate concentration $>0.70$ $\mathrm{mM}$ in the calibration curve of xanthine, that indicates the less accuracy and precision of measurement. Therefore, the electrochemical method can respond analyte more specifically and in the wider concentration range than the spectrophotometric method.

Sensitivity is the ratio of change in response per unit change in analyte concentration [26]. Sensitivity can be determined based on the slope value of the calibration curve [27]. The result showed that the electrochemical and spectrophotometric methods each gave a sensitivity value of $0.95 \mathrm{~mA} \mathrm{mM}^{-1}$ and 0.007 $\mathrm{min}^{-1}$. The higher of sensitivity value indicates that with a small change of concentration can provide a significant change in response [28]. Thus the electrochemical method was indicated to provide a better sensitivity than the spectrophotometric method in 


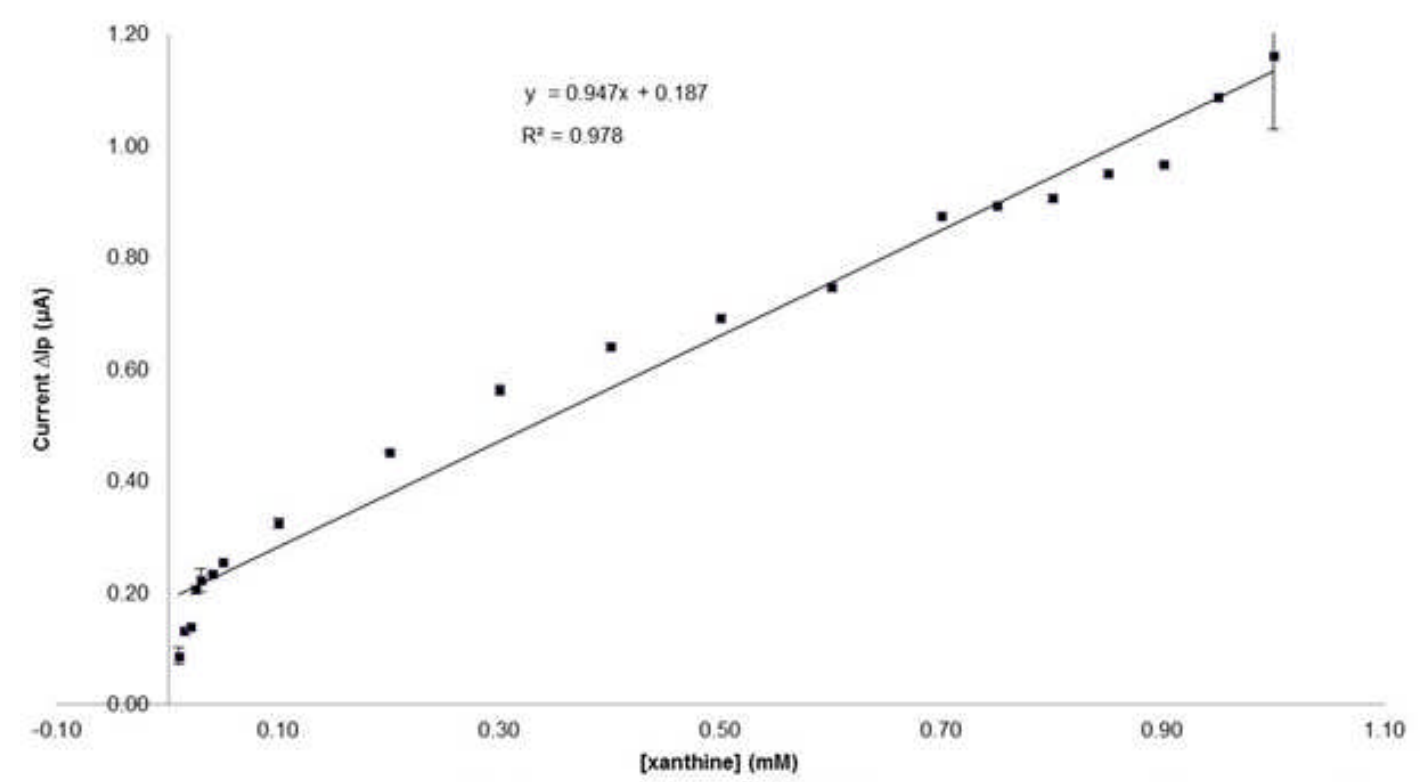

Fig 2. Linearity between xanthine and $X O$ activity $\left(V_{\max }\right)$ by electrochemical method

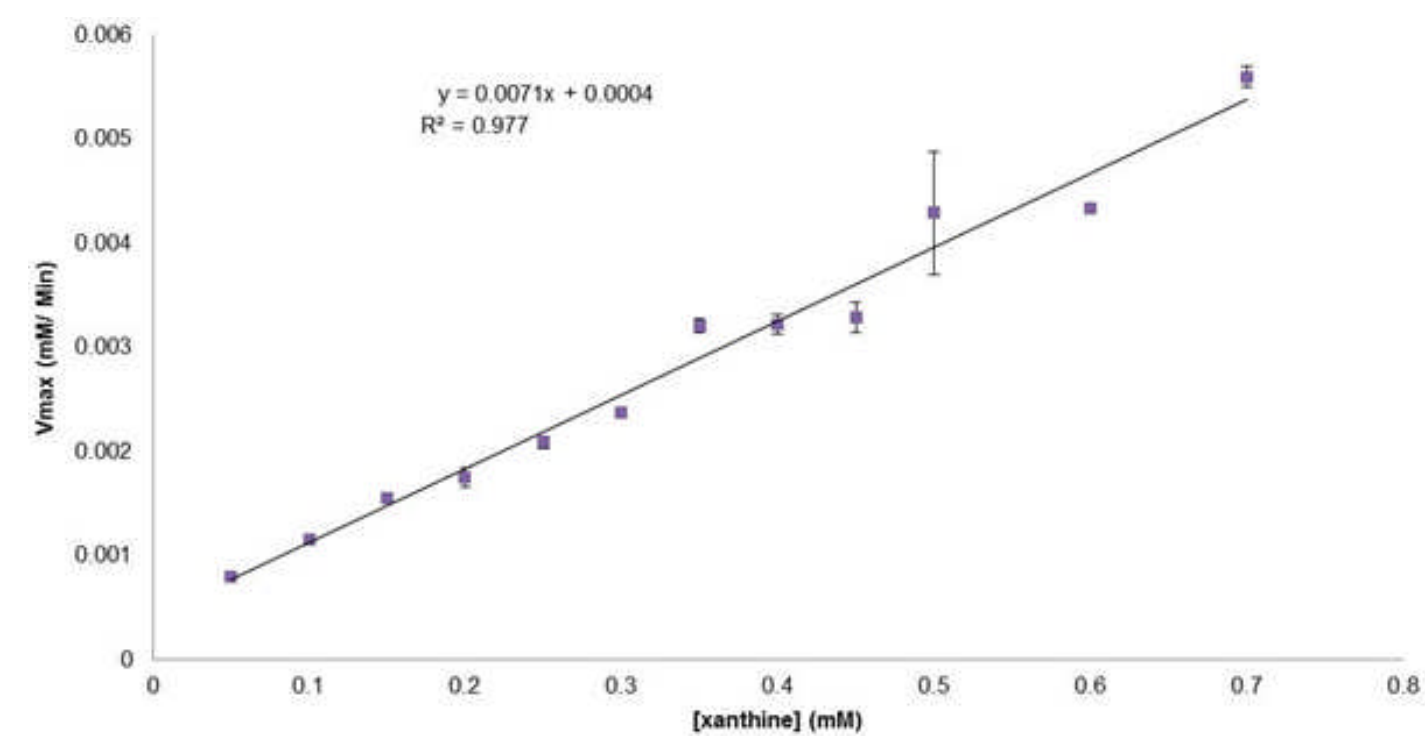

Fig 3. Linearity between xanthine and xanthine oxidase activity $\left(\mathrm{V}_{\max }\right)$ by spectrophotometric method

determining the velocity of enzymatic reactions that form the basis for determining the type of inhibition kinetics. The other researches by electrochemical methods were reported to give varying sensitivity values. A smaller sensitivity value, among others, was reported at $0.55 \mu \mathrm{A} \mathrm{mM}^{-1}[29]$ and $0.062 \mu \mathrm{A} \mathrm{mM}^{-1}[30]$. While the higher of sensitivity values was reported by Zhao et al. [31] of $29.5 \mu \mathrm{A} \mathrm{mM}{ }^{-1}$. The electrochemical method can also be reported more effectively than the spectrophotometric method in determining the type of inhibition kinetics because electrochemical method requires a shorter analysis time, higher sensitivity and the amount of material required is also relatively less than the spectrophotometric method.

\section{Kinetic Properties of XO}

Concentration of selected extracts in inhibition kinetics assay was $100 \mathrm{ppm}$. The selection was based on its high inhibitory activity ( $>50 \%$ ) and the closest concentration of $\mathrm{IC}_{50}$ extract values that had been obtained previously. Qualitative analysis of the enzymatic reaction is generally carried out by Michaelis-Menten curve, but the curve is very difficult to determine the value of $K_{M}$ and $V_{\max }$. Therefore, in this study the determination of $K_{M}$ dan $V_{\max }$ values was carried according to Lineweaver-Burk plot (Fig. 4).

Determination of the inhibition kinetics type was done by determining changes in the value of the 


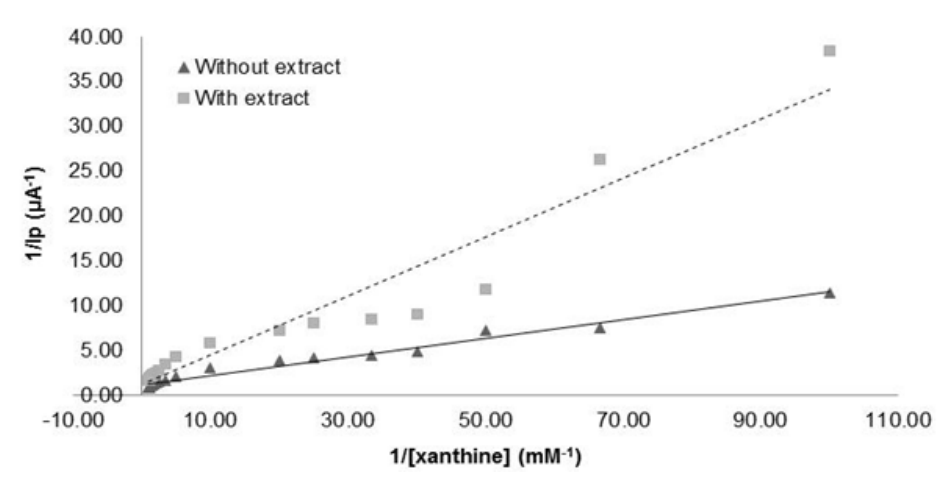

Fig 4. Lineweaver-Burk plot of $X O$ inhibition with various concentrations of xanthine, addition of $100 \mathrm{ppm}$ of ethanol extract of Sida rhombifolia L., without ethanol extract and Lineweaver-Burk transformed data were plotted and followed by linear regression of the point

Michaelis-Menten constant $\left(\mathrm{K}_{\mathrm{M}}\right)$ and maximum velocity $\left(V_{\max }\right)$ which is analogous to a maximum current $\left(I_{\max }\right)$. Based on the analysis of Lineweaver-Burk plot (Fig. 4), it resulted a significant change of $\mathrm{K}_{\mathrm{M}}$ value and very small $\mathrm{V}_{\max }$ change. The kinetic pattern that forms after the addition of extracts as inhibitors resulted in an increase in $\mathrm{K}_{\mathrm{M}}$ from $0.0855 \mathrm{mM}$ to $0.2718 \mathrm{mM}$, an increase of $68.73 \%$. The $I_{\max }$ value decreased from 0.82338 to 0.82325 and the small decrease in the $I_{\max }$ value could be assumed there was no change [32]. Based on the results it can be concluded that ethanol crude extract of this plant leads to the type of competitive inhibition kinetics as can be concluded from similar $V_{\max }$ and different $\mathrm{Km}$ values [33].

Electrochemical measurements give a smaller value of $K_{M}$ and a higher value of $V_{M a x}$ which were previously obtained on spectrophotometric measurements by Iswantini et al. [3]. $K_{M}$ is a measure of substrate affinity for the enzyme. The smaller the $K_{M}$ value obtained on electrochemical method shows that this method can measure the substrate affinity of the enzyme even at relatively lower concentrations than in the spectrophotometric measurements.

The inhibitor affinity value $(\alpha)$ of the enzyme can be determined by calculating the ratio between the value of $K_{M}$ with inhibitors and $K_{M}$ values without inhibitor. The inhibitor affinity ( $\alpha$ ) of extract was 3.18. These conditions indicate the existence of strong competition between the extract and the substrate to bind with the active sites of enzyme. The Competitive inhibition kinetics of $S$. Rhombifolia's ethanol extract found in this study reinforce the previous research by Iswantini et al. [3] which explains a competitive inhibition of $S$. Rhombifolia's flavonoids crude extract with smaller $\alpha$ value of this research, that is, 2.32.

\section{CONCLUSION}

The S. Rhombifolia's ethanol extract has a potential as $\mathrm{XO}$ inhibitor as indicated by its inhibitory activity up to $82.69 \%(200 \mathrm{ppm})$ and $\mathrm{IC}_{50}<100 \mathrm{mg} \mathrm{L}^{-1}$. Inibition kinetics of the ethanol extract caused a change of $K_{M}$ and similiar of $V_{\max }$. Thus, the type of inhibition kinetics leads a competitive inhibition, with an inhibitor affinity (a) value of 3.18. Electrochemical and spectrophotometric measurements showed a linear region of each measurement in the range of $0.01-1.00$ $\mathrm{mM}$ and $0.05-0.70 \mathrm{mM}$. The sensitivity of electrochemical method in velocity measurement was reported to be higher $\left(0.95 \mu \mathrm{A} \mathrm{mM}{ }^{-1}\right)$ than the spectrophotometric method $\left(0.007 \mathrm{~min}^{-1}\right)$. Electrochemical method provides fast analysis time, high sensitivity, easy operation, and inexpensive method in determining the type of inhibition kinetics.

\section{REFERENCES}

1. Akram, M., Asif, H.M., Usmanghani, K., Akhtar, N., Jabeen, Q., Madni, A., Saeed, T., Rehman, R., Ahmed K., and Shah, A., 2011, Afr. J. Biotechnol., 10 (6), 996-998.

2. Connor, M., 2009, Br. J. Pharmacol., 156, 1, 4-6.

3. Iswantini, D., Darusman, L.K., and Hidayat, R., 2009, J. Biol. Sci., 9 (5), 504-508.

4. Iswantini, D., Darusman, L.K., Rahminiwati, M., Iskandar, Heryanto, R., 2010, Formula Ekstrak Gabungan Apium Graveolens dan Sida Rhombifolia L. sebagai Fitofarmaka untuk Penyakit Gout: Inhibitir Xantin Oksidase, Patent ID P00200400339.

5. Pauff J.M., and Hille, R., 2009, J Nat Prod., 72 (4), 725-731.

6. Berboucha, M., Ayouni, K., Atmani, D., Atmani, D., and Benboubetra, M., 2010, J. Med. Food., 13 (4), 896-904.

7. Nile, S.H., and Khobragade, C.N., 2011, Indian J. Nat. Prod. Resour., 2 (1), 52-58.

8. Cengiz, S., Cavaz, L., Yurdakoc, K., and Aksu, S., 2012, Turk. J. Biochem., 37 (4), 445-451. 
9. Chen, G., Ni, S., Zhu, S., Yang, J., and Yin, Y., 2012, Int. J. Mol. Sci., 13 (3), 2801-2809.

10. Iswantini, D., Nurhidayat, N., Trivadila and Widiyatmoko, O., 2013, Pak. J. Biol. Sci., 1-5.

11. Campanella, L., Bonanni, A., Bellantoni, D., Favero, G., and Tomassetti, M., 2004, J. Pharm. Biomed. Anal., 36 (1), 91-99.

12. Grieshaber, D., MacKenzie, R., Voros, J., and Reimhult, E., 2008, Sensors, 8 (3), 1400-1458.

13. Fan, C., Plaxco, K.W., and Heeger, A.J., 2003, PNAS, 100 (16), 9134-9137.

14. Arslan, F., 2008, Sensors, 8 (9), 5492-5500.

15. Iveković, D., Japec, M., Solar, M., and Živković, N., 2012, Int. J. Electrochem. Sci., 7, 3252-3264.

16. Mirel, S., Sandulescu, R., Kauffmann, J.M., Roman, L., 1998, J. Pharm. Biomed. Anal., 18 (4-5), 535544.

17. Tamta, H., Kalra, S., and Mukhopadhyay, A.K., 2005, Biochemistry, 71 (Suppl. 1), S49-S54.

18. Kong, L.D., Cai, Y., Huang, W.W., Cheng, C.H.K., and Tan, R.X., 2000, J. Ethnopharmacol., 73 (1-2), 199-207.

19. Thuong, P.T., Na, M.K., Dang, N.H., Hung, T.M., Ky P.M., Thanh, T.V., Nam, N.H., Thuan N.D., Sok, D.E., and Bae, K.I., 2006, J. Nat. Prod. Sci., 12 (1), 29-37.

20. Umamaheswari, M., Asokkumar, K., Sivashanmugam, A.T., Remyaraju, A., Subhadradevi, V., and Ravi, T.K., 2009, J. Ethnopharmacol., 124 (3), 646-648.
21. Apaya, K.L., and Chicioco-Hernandeez, C.L., 2011, J. Med. Plant Res., 5 (2), 289-292.

22. Azmi, S.M.N., Jamal, P., and Amid, A., 2012, Int. Food Res. J., 19 (1), 159-165.

23. Septianingsih, U., Susanti, H., and Widyaningsih, W., 2012, Jurnal IImiah Kefarmasian, 2 (2), 153163.

24. Wang, S.Y., Yang, C.W., Liao, J.W., Zhen, W.W., Chu, F.H., and Chang, S.T., 2008, Phytomedicine, 15, 940-945.

25. Sarawek, S., 2007, Dissertation, Florida, University of Florida.

26. Indarti, D., and Asnawati, 2011, Jurnal IImu Dasar, 12 (2), 200-209.

27. Oliveira, J.E., Mattoso, L.H.C., Medeiros, E.S., and Zucolotto, V., 2012, Biosensors, 2 (1), 70-82.

28. Amri, C., Siswanta, D., and Mudasir, 2009, Indo. J. Chem., 9, 254-260.

29. Shan, C., Yang, H., Han, D., Zhang, Q., Ivaskab, A., and Niu, L., 2010, J. Biosens. Bioelectron., 25 (5), 1070-1074.

30. Demirkiran, N., and Ekinci, E., 2012, Acta Chim. Slov., 59 (2), 302-306.

31. Zhao, C., Wan, L., Wang, Q., Liu, S., and Jiao, K., 2009, Anal. Sci., 25, 1013-1017.

32. Iswantini, D., Nadinah, Darusman, L.K., and Trivadila, 2012, J. Biol. Sci., 9, 504-508.

33. Voet, D., and Voet, J.G., 2001, Biochemistry, John Wiley and Sons, New York, USA. 